\title{
Kurikulum Sejarah Jenjang SMA: Sebuah Perbandingan Indonesia-Australia
}

\author{
Oleh : Abrar \\ Pendidikan Sejarah PPS UNJ
}

\begin{abstract}
The purpose of this paper was to compare how the education system and curriculum history at secondary school level between Indonesia and Australia. The education system in Indonesia is not much different from Australia. History curriculum in Indonesia philosophically is more multi dimensional than Australia which essentialism as priority. Indonesian history curriculum is more comprehensive interms of content than Australia that is optional for students. The ability to interpret the history curriculum in Australiais more prominent than Indonesia.
\end{abstract}

Key words: education system, history curriculum, content.

\begin{abstract}
Abstrak
Tujuan dari tulisan ini adalah ingin membandingkan bagaimana sistem pendidikan dan kurikulum sejarah pada tingkat sekolah menengah atas antara Indonesia dan Australia. Sistem pendidikan di Indonesia tidak berbeda jauh dengan Australia. Secara filosofis kurikulum sejarah di Indonesia lebih multi dimensi dibandingkan dengan di Australia yang mengutamakan esensialisme.Kurikulum sejarah di Indonesia lebih luas dari sisi konten dibandingkan di Australia yang kontennya bersifat pilihan bagi peserta didik. Kemampuan menginterpretasi dalam kurikulum sejarah di Australia lebih menonjol dibandingkan dengan Indonesia.
\end{abstract}

Kata Kunci: sistem pendidikan, kurikulum sejarah, isi

\section{Pendahuluan}

Indonesia dan Australia memang negara yang berbeda dari berbagai segi seperti politik, ekonomi, demografi dan pendidikan. Meskipun berbeda dalam berbagai segi, tetapi dalam konteks pendidikan kiranya ada persamaan yakni tantangan zaman pada abad ke-21.Sensus penduduk yang dilakukan di Indonesia pada tahun 2010 menunjukkan jumlah penduduk Indonesia 237,6 juta. Jumlah penduduk usia produktif lebih banyak jumlahnya dibandingkan usia penduduk tidak produktif. Pada tahun 2020-2035 diperkirakan jumlahnya mencapai $70 \%$. Tantangan lainnya adalah makin kuatnya pengaruh globalisasi sehingga mau tidak mau penduduk usia produktif itu akan berhadapan dengan masyarakat industri dan perdagangan modern. Hal itu dapat dilihat makin kuatnya pengaruh ekonomi negara-negara seperti India dan Cina. Belum lagi makin kompleksnya tekanan terkait masalah lingkungan seperti perubahaniklim. Tantanganyang demikian itu juga dihadapi oleh Australia. Australia berusaha mengantisipasi perkembangan yang bakal terjadi itu sampai tahun 2022 . Generasi muda Australia harus mampu menyesuaikan diri dengan perkembangan ilmu pengetahuan dan keterampilan yang menjawab tantangan zaman itu. Dalam hal itu baik Indonesia maupun Australia mesti mempersiapkan generasi muda yang 
mampu menghadapi tantangan tersebut. Terkait dengan konteks pendidikan itu yang menarik untuk menjadi perhatian adalah kurikulum pendidikan yang berlaku di kedua negara itu dalam menyiapkan generasi muda mereka.

Indonesia telah menjalankan beberapa kurikulum dalam upaya mencerdaskan kehidupan bangsa sesuai dengan amanat pembukaan Undang-Undang Dasar 1945. Terakhir diterapkan kurikulum yang disebut kurikulum 2013.Sebelumnya kurikulum yang berlaku adalah kurikulum 2006 yang sering dikenal dengan nama Kurikulum Tingkat Satuan Pendidikan (KTSP). Penerapan kurikulum 2013 merupakan perubahan yang dilakukan pemerintah dalam rangka menghadapi tantangan zaman. Penerapan kurikulum itu menimbulkan kontroversi dikalangan akademisi maupun masyarakat. Pada akhirnya penerapan kurikulum itu belum dilaksanakan secara nasional, karena menunggu selesai dilakukan evaluasi. Penerapan kurikulum di Indonesia berlakunya bersifat nasional. Tidak ada kurikulum yang berlaku sesuai dengan kondisi di setiap provinsi.

Australia jumlah penduduknya sekarang ini diperkirakan sekitar 23 juta. Berdasarkan hasil sensus penduduk tahun 2011 jumlahnya mencapai 21.507.719 jiwa. Luas wilayahnya $7.692 .000 \mathrm{~km}^{2}$ dengan etnis yang beraneka ragam pula. Bentuk negara Australia adalah federal dengan sistem pemerintahannya parlementer. Sebagai negara berbentuk federal Australia dipersatukan dalam suatu federasi yang disebut persemakmuran (commonwealth). Federasi Australia itu terbentuk pada tahun 1901 yang terdiri dari enam negara bagian dan dua teritori (Nur,2001:57). Keenam negara bagian itu adalah New South Wales (NSW), Queensland (QLD), South Australia (SA), Tasmania (TAS),
Victoria (VIC), dan Western Australia (WA). Sedangkan dua wilayah teritori adalah Australian Capital Territory (ACT) dan Northern Territory (NT). Secara politik sistem yang berlaku di Australia berbasiskan demokrasi liberal dengan multi partai. Setidaknya ada empat partai utama di Australia yaitu Partai Buruh Australia, Partai Liberal, Parta Nasional Australia dan Partai Hijau Australia.

Australia negara tetangga yang berada di sebelah selatan Indonesia juga melakukan perubahan kurikulum. Untuk jenjang pendidikan Senior Secondary kurikulum resmi yang digunakan di Australia adalah kurikulum 2012. Kurikulum 2012 yang diberlakukan di Australia bersifat panduan umum yang merupakan standar nasional untuk meningkatkan kompetensi seluruh generasi muda Australia.Sehingga bagi negara bagian dan teritori dalam menerapkan kurikulum agar sesuai dengan standar nasional tersebut. Kurikulum itu proses perumusannya telah dilakukan sejak tahun 2010 ketika draftnya yang terkait konten pertama kali disosialisasikan.

Ada dua permasalahan pokok yang dapat diangkat dalam melihat perbedaan antara Indonesia dengan Australia dalam tulisan ini.Bagaimana sistem pendidikan yang berlaku di Indonesia dan Australia? Bagaimana kurikulum khususnya kurikulum pendidikan sejarah yang berlaku di kedua negara tersebut pada jenjang pendidikan menengah?

\section{KAJIAN TEORETIK}

Membicarakan sistem pendidikan perlu pemahaman tentang pengertian sistem.Sistem menurut Amirin sebagaimana dikutip Tirtarahardja dan 
La Sulo (2012:57) adalah himpunan komponen yang saling berkaitan yang bersama-sama berfungsi untuk mencapai suatu tujuan. Hal yang sama dikemukakan oleh Hafid, Jafar Ahiri dan Pendais Haq (2014:80) Byang menyatakan sistem adalah jumlah keseluruhan dari bagian-bagian yang saling bekerja sama untuk mencapai suatu tujuan. Tirtarahardja dan La Sulo juga menyatakan bahwa sistem adalah suatu kesatuan integral dari sejumlah komponen yang saling berpengaruh dengan fungsinya masing-masing dalam rangka mencapai suatu tujuan.

Dengan demikian sistem merupakan suatu rangkaian komponen yang saling terkait satu dengan yang lain yang berfungsi untuk mencapai suatu tujuan. Jika dikaitkan dengan pendidikan berarti tujuan yang mau dicapai adalah tujuan pendidikan. BerdasarkanUndang-Undang Sistem Pendidikan Nasional tujuan itu menyangkut tujuan pendidikan nasional. Oleh karena itu sistem pendidikan nasional menurut UU No.20 Tahun 2003 adalah keseluruhan komponen pendidikan yang saling terkait secara terpadu untuk mencapai tujuan pendidikan nasional. Komponen sistem pendidikan itu terdiri dari tujuan, organisasi, masa, prasarana, sarana, isi pendidikan, tenaga pendidikan dan peserta didik. (Redja Mudyahardjo, 2014:64-70).

Dari berbagai komponen yang ada dalam sistem pendidikan itu yang dibahas dalam tulisan ini hanya masalah tujuan, organisasi, masa, dan isi pendidikan. Mudyahardjo menjelaskan bahwa tujuan itu terkait dengan tujuan umum pendidikan yang dalam hal itu adalah tujuan pendidikan nasional. Organisasi berkaitan dengan pengelolaan pendidikan yang dalam hal itu pemerintah baik pusat atau daerah, dan organisasi pendidikan yang berkaitan dengan sistem persekolahan. Masa maksudnya adalah jangka waktu berlangsungnya keseluruhan kegiatan dalam satuan pendidikan atau keseluruhan kegiatan semua satuan-satuan pendidikan. Sedangkan isi pendidikan menyangkut pengalaman-pengalaman yang dipelajari peserta didik selama proses pendidikan. Hal itu berhubungan dengan kurikulum yang digunakan agar tujuan pendidikan dapat tercapai.

Kurikulum menurut Decker (1990:4) secara konseptual akan memunculkan berbagai macam definisi. Ada yang menyatakan kurikulum adalah aktivitas belajar secara terencana yang dilakukan sekolah. Ada juga yang menyatakan situasi atau aktivitas yang dirancang oleh guru agar siswa belajar. Yang lain menyatakan bahwa kurikulum itu adalah serangkaian kejadian yang mempunyai potensi untuk membangun pengalaman manusia.Dari ketiga definisi tersebut nampak bahwa kurikulum itu pada dasarnya bagaimana agar terjadi aktivitas belajar di kalangan siswa. Sementara dalam Undang-undang Sistem Pendidikan Nasional diungkapkan bahwa kurikulum adalah seperangkat rencana dan pengaturan mengenai tujuan, isi, dan bahan pelajaran serta cara yang digunakan sebagai pedoman penyelenggaraan kegiatan pembelajaran untuk mencapai tujuan pendidikan tertentu.

Meskipun ada berbagai pendapat tersebut, Walker (1990:5) mengingatkan kepada kita bahwa paling tidak ada lima konsep kurikulum yaitu subjects offered for study, educational activities, intended learning, student's experiences, and learning outcomes. Walker menjelaskan bahwa subject offered for study maksudnya adalah apa yang menjadi mata pelajaran yang bakal diberikan kepada siswa. Educational activities adalah apa aktivitas 
yang dilakukan siswa di dalam kelas yang mendukung kegiatan belajar. Intended learning adalah apa yang diharapkan atau yang mau dicapai siswa dalam belajar. Student's experiences adalah apa pengalaman nyata yang didapatkan siswa melalui bimbingan dan arahan yang terjadi di sekolah. Sedangkan learning outcomes adalah apa hasil nyata yang dicapai siswa setelah proses belajar terjadi.

\section{HASIL DAN PEMBAHASAN}

\section{Sistem Pendidikan}

Pendidikan sebagai upaya sadar pada dasarnya bermaksud mencapai tujuan tertentu. Tujuan tertentu pendidikan setiap negara di dunia berbeda antara satu dengan yang lain, termasuk Indonesia dan Australia. Indonesia tujuan pendidikan nasionalnya adalah untuk berkembangnya potensi peserta didik agar menjadi manusia yang beriman dan bertaqwa kepada Tuhan Yang Maha Esa, berakhlak mulia, sehat, berilmu, cakap, kreatif, mandiri, dan menjadi warga negara yang demokratis serta bertanggung jawab. Tujuan berbagai sektor pendidikan Australia didasarkan pada undang-undang yang berlaku dalam bidang pendidikan di setiap negara bagian, universitas, dan lembaga pendidikan lainnya. Pada level sekolah misalnya untuk pengembangan potensi peserta didik, dan pada level pendidikan tinggi bertujuan untuk kepentingan ekonomi serta masyarakat secara umum. Sedangkan pemerintah federal Australia merumuskan tujuan pendidikan sebagaimana yang tertuang dalam Melbourne Declaration on Educational Goals for Young Australians pada tahun 2008. Ada dua tujuan yang dirumuskan dalam Melbourne Declaration itu yaitu (1) mengembangkan kesetaraan dan keunggulan generasi muda Australia dan (2) seluruh generasi muda Australia menjadi pembelajar yang sukses, individu yang percaya diri dan kreatif, dan menjadi warga negara yang aktif dan inspiratif. Melbourne Declaration itu merupakan rumusan yang dihasilkan oleh semua Menteri Pendidikan Australia baik dari pemerintah federal maupun pemerintah negara bagian. Apa yang dirumuskan melalui itu kemudian diadopsi ke dalam Australian Education Act 2013 yang di dalamnya menyatakan bahwa semua siswa di semua sekolah berhak atas pendidikan yang sangat baik, yang memungkinkan setiap siswa untuk mencapai potensi penuhnya sehingga ia bisa sukses, mencapai aspirasinya, dan memberikan kontribusi sepenuhnya kepada masyarakatnya, di masa sekarang danmasa depan. Baik tujuan pendidikan Indonesia maupun tujuan pendidikan Australia memperlihatkan betapa pentingnya kualitas manusia yang mau diupayakan secara sadar melalui pendidikan. Terkait dengan kualitas itu Australian Education Act 2013 menegaskan tidak boleh dibatasi oleh dimana ia tinggal, pendapatan keluarganya, sekolah yang diikutinya atau keadaan pribadinya. Sebelumnya dalam Australian Education Bill 2012disebutkan tujuan pendidikan dalam rangka agar sekolah di Australia memberikan pendidikan yang sangat baik bagi peserta didik, berlaku sangat adil dan menempatkan Australia dalam lima negara yang berkualitas dalam lomba internasional di bidang membaca, sains dan matematika. Dalam mencapai tujuan pendidikan itu dapat dilakukan dengan menciptakan sistem pendidikan yang mendukung untuk itu.

Sebagai suatu sistem pengelolaan pendidikan di Indonesia menjadi tanggungjawab pemerintah pusat. Tanggungjawab itu ada ditangan Menteri Pendidikan dan Kebudayaan. Meskipun tanggungjawab pengelolaan sistem 
pendidikan itu ada ditangan Menteri, bukan berarti dalam penyelenggaraan pendidikan tidak melibatkan pemerintah derah. Pemerintah daerah dan bahkan masyarakat justru ikut dalam menyelenggarakan pendidikan. Sedangkan diAustralia sistem pengelolaan pendidikan menjadi tanggungjawab negara bagian atau teritori. Artinya tanggungjawab ada ditangan Menteri Pendidikan negara bagian.Sedangkan untuk penyelenggaraan pendidikan selain dilakukan oleh pemerintah negara bagian juga dapat diselenggarakan oleh masyarakat. Jadi baik Indonesia maupun Australia dalam hal penyelenggaraan pendidikan itu sama-sama ada yang dikelola pemerintah (negeri) dan ada yang dikelola swasta.

Penyelenggaraan pendidikan itu di Indonesia dari sisi jalur pendidikan terdiri daripendidikan formal, non formal, dan informal. Sedangkan jika dilihat dari segi jenjang pendidikan terdiri atas pendidikan dasar, pendidikan menengah, dan pendidikan tinggi. Sementara dari sisi jenis pendidikan didalamnya mencakup pendidikan umum, kejuruan, akademik, profesi, vokasi, keagamaan, dan khusus. Tidak berbeda jauh dengan Indonesia, di Australia jalur pendidikan dapat dibedakan atas pendidikan formal dan pendidikan non formal. Sementara dari segi jenjang pendidikan terdiri atas pendidikan dasar, pendidikan menengah, dan pendidikan tinggi. Sedangkan dari sisi jenis pendidikan terdapat pendidikan umum, vokasi, akademik, dan profesi.

Pendidikan dasar di Indonesia dimulai sejak Sekolah Dasar (SD) atau Madrasah Ibtidaiyah (MI) sampai dengan Sekolah Menengah Pertama (SMP) atau Madrasah Tsanawiyah (MTs).SD atau MI berlangsung selama 6 tahun dan SMP atau MTs berlangsung 3 tahun. Artinya pendidikandasar di Indonesiaberlangsung 9 tahun yang dimulai dari kelas 1 sampai dengan kelas 9. Pendidikan dasar itu wajib diikuti oleh setiap warga Negara Indonesia yang berusia 7 sampai dengan 15 tahun. Sebelum masuk pendidikan dasar peserta didik di Indonesia mengikuti pendidikan prasekolah. Sering juga disebut sebagai Pendidikan Anak Usia Dini (PAUD). Pendidikan prasekolah itu bentuknya seperti Taman Kanak-Kanak (TK), dan Raudatul Athfal (RA). Di samping itu peserta didik sebelum masuk TK ataupun RA, mereka mengalami pendidikan dalam kelompok yang disebut Kelompok Bermain dan Taman Penitipan Anak.

Pendidikan dasar di Australia dinamakan Primary School (PS) yang berlangsung selama 6 atau 7 tahun dan Secondary School (SS) yang berlangsung selama 3 atau 4 tahun tergantung ketentuan dari masing-masing negara bagian. Pendidikan dasar itu wajib diikuti oleh peserta didik yang berusia antara 6 sampai 16 tahun.

Primary School di Negara Bagian New South Wales, Victoria, Tasmania, dan Australia Capital Territory berlangsung sampai level 6. Sedangkan di Negara Bagian South Australia, Northern Territory, Queensland, dan Western Australiaberlangsung sampai level 7 . Sama halnya dengan di Indonesia, di Australia juga ada pendidikan prasekolah (preschool). Hanya saja setiap negara bagian berbeda-beda penamaannya. Pendidikan Preschool itu diikuti peserta didik usia 3-4 tahun dan bukan sesuatu yang wajib untuk diikuti. Australia juga mengenal yang namanya Preparatory yang dalam pelaksanaannya hampir semua negara bagian itu menjadi bagian integral dari PS karena itu merupakan masa persiapan untuk masuk PS kecuali di Negara Bagian Western Australia. Usia untuk masuk 
Preparatory rata-rata 5 tahun. Penamaan untuk Preparatory itupun berbeda-beda di setiap negara bagian.

Sesudah menempuh SD peserta didik di Indonesia dapat melanjutkan pendidikan dasar ke SMP atau MI, sedangkan di Australia peserta didik setelah menyelesaikan pendidikan di PS melanjutkan pendidikannya ke SS. Lama belajar di SMP atau MI berlangsung 3 tahun, sementara di Australia lama belajar di SS harus mengikuti ketentuan negara bagian masing-masing. Pada saat peserta didik Indonesia masuk SMP atau MI berarti mereka sudah masuk belajar pada kelas 7 sampai dengan 9. Negara Bagian New South Wales, Victoria, Tasmania dan Australia Capital Territory lama belajar di SS 4 tahun. Itu berarti berada pada level 7 sampai level 10. Dalam pada itu di Negara Bagian South Australia, Northern Territory, Queensland dan Western Australia lama belajar di SS hanya 3 tahun. Selama tiga tahun itu peserta didik belajarnya masuk pada level 8 sampai level 10 .
Selesai menempuh pendidikan dasar baik peserta didik di Indonesia maupun di Australia selanjutnya melanjutkan pendidikannya ke pendidikan menengah. Jika di Indonesia pendidikan menengah berlangsung selama 3 tahun, maka di Australia pendidikan menengah berlangsung 2 tahun. Pendidikan menengah di Indonesia dibedakan atas dua yaitu pendidikan menengah umum dan pendidikan menengah kejuruan. Pendidikan menengah umum bentuknya Sekolah Menengah Atas (SMA) atau Madrasah Aliyah (MA) dan pendidikan menengah kejuruan bentuknya adalah Sekolah Menengah Kejuruan (SMK) dan Madrasah Aliyah Kejuruan (MAK).Pada saat belajar di pendidikan menengah itu peserta didik Indonesia sudah masuk pada kelas 10 sampai dengan kelas 12.Pendidikan menengah di Australia disebut Senior Secondary School (SSS). SSS yang berlangsung hanya 2 tahun itu dalam sistem pendidikan Australia sudah berada pada level 11 dan 12. Berikut ini perbandingan struktur sekolah di Indonesia dan Australia.

\section{Bagan Perbandingan Struktur Sekolah Indonesia dan Australia}

\begin{tabular}{|c|c|c|c|c|c|}
\hline \multirow[b]{2}{*}{ KELAS } & \multirow[b]{2}{*}{ INDONESIA } & \multirow[b]{2}{*}{ LEVEL } & \multicolumn{3}{|c|}{ AUSTRALIA } \\
\hline & & & $\begin{array}{c}\text { NSW, VIC,TAS, } \\
\text { ACT }\end{array}$ & SA,NT & QLD,WA \\
\hline 12 & \multirow{3}{*}{$\begin{array}{l}\text { SMA/MA/ } \\
\text { SMK/MAK }\end{array}$} & 12 & \multirow[b]{2}{*}{ SSS } & \multirow[b]{2}{*}{ SSS } & \multirow[b]{2}{*}{ SSS } \\
\hline 11 & & 11 & & & \\
\hline 10 & & 10 & \multirow{4}{*}{ SS } & \multirow{3}{*}{ SS } & \\
\hline 9 & \multirow{3}{*}{ SMP/MTs } & 9 & & & \\
\hline 8 & & 8 & & & \\
\hline 7 & & 7 & & & \\
\hline
\end{tabular}




\begin{tabular}{|c|c|c|c|c|c|}
\hline & \multirow{6}{*}{ SD/MI } & 6 & \multirow{6}{*}{ PS } & \multirow{6}{*}{ PS } & \multirow{6}{*}{ PS } \\
\hline & & 5 & & & \\
\hline & & 4 & & & \\
\hline & & 3 & & & \\
\hline & & 2 & & & \\
\hline & & 1 & & & \\
\hline \multirow[t]{2}{*}{ PRASEKOLAH } & TK/RA & Preepatory & $\begin{array}{l}\text { Kindergarten(NST, } \\
\text { VIC, ACT), } \\
\text { Preschool (TAS) }\end{array}$ & $\begin{array}{l}\text { Transition } \\
\text { (NT), } \\
\text { Reception } \\
\text { (SA) }\end{array}$ & $\begin{array}{l}\text { Preparatory } \\
\text { (QLD),Pre- } \\
\text { primary } \\
\text { (WA) } \\
\end{array}$ \\
\hline & КВ/ТPA & Preschool & $\begin{array}{l}\text { Preschool (NST, } \\
\text { VIC, ACT), } \\
\text { Kindergarten (TAS) }\end{array}$ & $\begin{array}{l}\text { Preschool } \\
\text { (NT, SA) }\end{array}$ & $\begin{array}{l}\text { Kindergarten } \\
\text { (QLD,WA) }\end{array}$ \\
\hline
\end{tabular}

Nampaknya ada perbedaan dalam menerapkan konsep pendidikan dasar di Indonesia dengan Australia. Indonesia pendidikan dasarnya berlangsung dari kelas 1 sampai kelas 9. Sedangkan Australia pendidikan dasarnya berlangsung dari level 1 sampai level 10. Dengan demikian peserta didik di Indonesia dari segi usia menyelesaikan pendidikan dasarnya pada usia 15 tahun sedangkan di Australia dalam pada usia 16 tahun. Artinya secara psikologi tingkat kematangan berpikir peserta didik Australia lebih dewasa dari peserta didik Indonesia. Untuk pendidikan menengah Indonesia sudah melakukan pemilahan antara yang umum dengan kejuruan, sementara di Australia tidak terjadi hal yang demikian itu.

Jenjang berikut yang ditempuh peserta didik Indonesia setelah menempuh pendidikan menengah adalah pendidikan tinggi. Jenjang pendidikan tinggi itu didalamnya terdapat program pendidikan diploma, sarjana, magister, spesialis dan doktor yang bentuknya meliputi akademi, politeknik, sekolah tinggi, institut, dan universitas. Akademi merupakan program pendidikan tinggi yang menyelenggarakan pendidikan vokasi pada satu bidang tertentu.
Sebaliknya politeknik menyelenggarakan pendidikan vokasi pada beberapa bidang ilmu pengetahuan dan teknologi.Lama pendidikan pada program diploma baik yang diselenggarakan jenjang akademi maupun politeknik berlangsung antara 1 sampai 3 tahun. Gelar yang diperoleh dari program Diploma 1 adalah Ahli Pratama (A. P), Diploma 2 adalah Ahli Muda (A. Ma) dan Diploma 3 adalah Ahli Madya (A. Md). Tamatan Diploma 3 (A. Md) dapat melanjutkan pendidikannya ke program Diploma 4 dengan gelar Sarjana Sains Terapan (S. ST.) atau S1 dengan gelar Sarjana (S). Akademi dan politeknik itu dalam menerima peserta didik biasanya berasal dari lulusan SMA/SMK atau MA/ MAK.

Sekolah Tinggi, Institut dan Universitas di Indonesia merupakan jenjang pendidikan tinggi yang dapat ditempuh sebagai kelanjutan dari pendidikan menengah. Selain menerima peserta didik yang berasal dari lulusan pendidikan menengah, lembaga tersebut juga menerima yang berasal dari lulusan Diploma 3. Jenjang pendidikan tinggi itu dapat dibedakan atas dua bagian yaitu jenjang sarjana dan jenjang pascasarjana. Jenjang sarjana (S1) lama studinya antara 
4-7 tahun. Sebutan gelar sarjananya tergantung bidang studi yang ditempuh peserta didik. Pada jenjang pascasarjana baik di sekolah tinggi, institute maupun universitas terdapat dua program yaitu program Sarjana 2 (S2) dengan gelar Magister dan program Sarjana 3 (S3) dengan gelar Doktor. Program S2 berlangsung antara 2-3 tahun dan program S3 berlangsung antara 2-4 tahun. Program magister dan doktor tidak hanya untuk pengembangan akademik, tetapi ada juga untuk terapan. Program magister terapan merupakan kelanjutan dari program sarjana terapan. Sedangkan doktor terapan adalah kelanjutan dari magister terapan. Selain itu pendidikan tinggi juga menyelenggarakan program profesi dan spesialis. Gelar lulusan itu sesuai dengan profesi atau spesialis yang ditempuh peserta didik yang lama belajarnya antara 2-3 tahun.

Selesai pendidikan menengah peserta didik di Australia masuk pendidikan yang disebut Tertiary Education (TE). Tertiary education terdiri dari pendidikan tinggi dan pendidikan vokasi. Sebelum masuk ke jenjang pendidikan tinggi peserta didik di Australia saat di level 11 sudah mempersiapkan diri. Apabila mereka berminat dalam bidang ilmu aplikatif maka mereka dapat melanjutkan ke pendidikan vokasi yang disebut Vocational Educationand Training (VET). Bahkan untuk pendidikan vokasi itu juga ditawarkan bagi peserta didik yang selesai dari program Secondary School. Jadi bukan hanya buat lulusan Senior Secondary School. Sedangkan bagi mereka yang ingin mendalami ilmu yang bersifat teoretik maka mereka masuk ke pendidikan tinggi yang disebut University (Universitas).

Jenjang pendidikan vokasi didasarkan atas kerjasama pemerintah dan industri. Kualifikasi VET disediakan oleh Australian
Qualifications Framework (AQF) mulai level 1 sampai 6 dan level 8. Kualifikasi VET AQF berbasis hasil dengan fokus pada keterampilan kerja dan kompetensi yang dicapai. AQF mengakui pembelajaran sebelumnya atau kompetensi saat ini dengan mentransfer sertifikat secara fleksibel. Paket pelatihan dan kursus terakreditasi yang disediakan oleh Registered Training Organisations (RTOs) mengarah pada kualifikasi AQF berikut: (1).certificate I, certificate II, Sertificate III dan certificate IV, (2). Diploma and Advanced Diploma, (3).Vocational Graduate Certificate dan Vocational Graduate Diploma. VET dapat dilakukan di sekolah-sekolah, tempat kerja, organisasi pelatihan, magang dan pendidikan jarak jauh.

Jenjang pendidikan universitas di Australia terdiri dari jenjang sarjana (undergraduate level) dan pascasarjana (postgraduate level). Jenjang sarjana ditempuh dalam waktu 3 tahun dan bagi lulusannya memperoleh gelar Bachelor. Bagi mereka yang ingin melanjutkan studinya ke jenjang pascasarjana, mereka terlebih dahulu harus mengikuti program Bachelor Honour Degree yang berlangsung selama 1 tahun. Lulusan program itu memperoleh gelar Bachelor Hons. Bagi lulusan Bachelor Hons yang kualifikasinya masuk kelompok atas (First Class dan Second Class), mereka dapat langsung masuk program doktor dan tidak menempuh program master.

Jenjang pascasarjana dapat dibedakan atas program Graduate Certificate, Graduate Diploma, Master Degree dan Doctoral Degree. Baik Graduate Certificate maupun Graduate Diploma dirancang bagi para profesional atau keterampilan bekerja sangat tinggi. Perbedaannya hanya dalam lama masa studinya dimana untuk program Graduate Certificate berlangsung selama 1 semester, sedangkan untuk Graduate Diploma 
lamanya 1 tahun. Program Master Degree berlangsung selama 18 bulan sampai 2 tahun yang dapat ditempuh melalui perkuliahan (by coursework), penelitian (by research) atau kombinasi perkuliahan dan penelitian (by extended).Bagi yang lulus program Master Degree memperoleh gelar Master. Program Doctoral Degree secara substansi buat yang berkontribusi terhadap ilmu pengetahuan yang merupakan karya asli sebagai pengetahuan baru. Program doktor itu berlangsung selama 3-4 tahun yang dapat dilakukan dalam bentuk perkuliahan (by professional) dan penelitian (by research).
Kurikulum Pendidikan Sejarah dan Landasan Filosofisnya

Program pendidikan yang dilaksanakan satuan pendidikan baik jenjang pendidikan dasar, menengah maupun tinggi mempunyai struktur kurikulum tertentu yang harus dilaksanakan oleh satuan pendidikan tersebut. Struktur kurikulum pendidikan menengah di Indonesia untuk tingkat Sekolah Menengah Atas dapat dibedakan atas dua bagian yaitu kelompok umum dan kelompok peminatan. Struktur tersebut dapat dilihat pada tabel untuk tingkat Sekolah Menengah Atas dapat dibedakan atas dua bagian yaitu kelompok umum dan kelompok peminatan. Struktur tersebut dapat dilihat pada tabel berikut:

\section{Struktur Kurikulum SMA/MA Kelompok Umum}

\begin{tabular}{|l|l|l|l|}
\hline \multirow{2}{*}{ Mata Pelajaran } & \multicolumn{3}{c|}{ Alokasi Waktu Perminggu } \\
\cline { 2 - 4 } & Kls X & Kls XI & Kls XII \\
\hline Kelompok A (Umum) & & & \\
\hline - Pendidikan Agama dan Budi Pekerti & 3 & 3 & 3 \\
\hline - Pendidikan Pancasila dan Kewarganegaraan & 2 & 2 & 2 \\
\hline - Bahasa Indonesia & 4 & 4 & 4 \\
\hline - Matematika & 4 & 4 & 4 \\
\hline - Sejarah Indonesia & 2 & 2 & 2 \\
\hline - Bahasa Inggris & 2 & 2 & 2 \\
\hline
\end{tabular}

\begin{tabular}{|c|c|c|c|}
\hline \multirow[t]{2}{*}{ Mata Pelajaran } & \multicolumn{3}{|c|}{ Mata Pelajaran } \\
\hline & KIs X & KIs XI & KIs XII \\
\hline \multicolumn{4}{|l|}{ Kelompok B (Umum) } \\
\hline -Seni Budaya & 2 & 2 & 2 \\
\hline -Pendidikan Jasmani, Olahraga, dan Kesehatan & 3 & 3 & 3 \\
\hline -Prakarya dan Kewirausahaan & 2 & 2 & 2 \\
\hline - Jumlah jam kelompok A dan B perminggu & 24 & 24 & 24 \\
\hline \multicolumn{4}{|l|}{ - Kelompok C (Peminatan) } \\
\hline -Mata pelajaran peminatan akademik & 9 atau 12 & 12 atau 16 & 12 atau 16 \\
\hline $\begin{array}{l}\text {-Mata pelajaran pilihan lintas minat dan/ } \\
\text { pendalaman minat }\end{array}$ & 6 atau 9 & 4 atau 8 & 4 atau 8 \\
\hline -Jumlah jam kelompok $A, B$, dan $C$ perminggu & 42 & 44 & 44 \\
\hline
\end{tabular}


Struktur Kurikulum SMA/MA Kelompok Peminatan

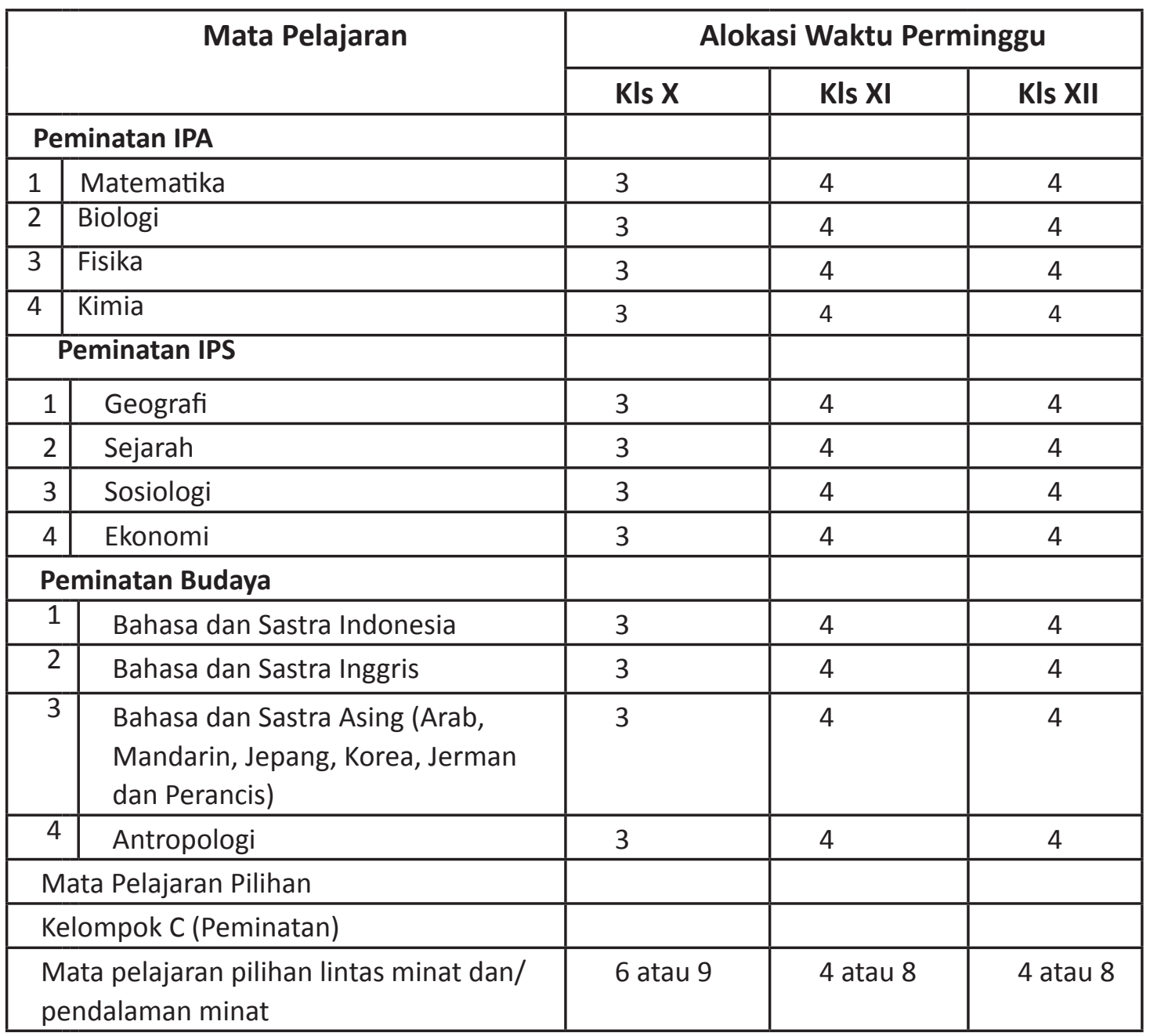

Struktur kurikulum SMA/MA baik kelompok umum maupun kelompok peminatan nampaknya berangkat dari pemikiran esensialisme. Pandangan esensialisme menuntut agar mata pelajaran yang diberikan kepada peserta didik secara eksplisit menunjukkan displin ilmu tertentu termasuk sejarah, bukan merupakan gabungan dari berbagai disiplin ilmu (Hasan, 2012:4). Sebab filosofi esensialisme pada dasarnya menginginkan dalam pembelajaran itu untuk mengembangkan kemampuan intelektual peserta didik. Jika memperhatikan jumlah jam maka kalau jam belajar efektif di Indonesia ada 4,5 bulan per semester maka berarti peserta didik yang belajar Sejarah Indonesia membutuhkan waktu 36 jam per semester, sementara bagi yang mengambil sejarah membutuhkan waktu antara 54-72 jam per semester.

Tidak berbeda dengan Indonesia, kurikulum Senior Secondary School Australia memperlihatkan juga suatu pemikiran yang bersifat esensialisme. Hal itu dapat dilihat dari penamaan mata pelajaran sebagaimana tergambar dalam tabel berikut ini. 
Struktur Kurikulum Senior Secondary School (SSS)

\begin{tabular}{|c|c|c|c|}
\hline \multirow[t]{2}{*}{ Learning Areas } & \multirow[t]{2}{*}{ Subject } & \multicolumn{2}{|c|}{ Time Allocation } \\
\hline & & Level XI & Level XII \\
\hline \multirow[t]{4}{*}{ English } & English & & \\
\hline & $\begin{array}{l}\text { English as an Additional Language } \\
\text { or Dialect }\end{array}$ & & \\
\hline & Essential English & & \\
\hline & Literature & & \\
\hline \multirow[t]{4}{*}{ Mathematic } & Essential Mathematics & & \\
\hline & General Mathematics & & \\
\hline & Mathematical Methods & & \\
\hline & Specialist Mathematics & & \\
\hline \multirow[t]{4}{*}{ Sciences } & Biology & & \\
\hline & Chemistry & & \\
\hline & Earth and Enviromental Science & & \\
\hline & Physics & & \\
\hline \multirow{3}{*}{$\begin{array}{l}\text { Humanities and Social } \\
\text { Sciences }\end{array}$} & Ancient History & & \\
\hline & Geography & & \\
\hline & Modern History & & \\
\hline
\end{tabular}

Setiap mata pelajaran yang ada dalam kurikulum itu terdiri dari beberapa unit. Secara umum rentang waktu setiap unit antara 50-60 jam per semester. Oleh karena Sejarah Kuno dan Sejarah Modern terdiri dari empat unit maka rentang waktu yang dibutuhkan dalam proses pembelajaran di Australia sekitar 200-240 jam per semester. Untuk pelaksanaannya setiap negara bagian diberi keleluasaan untuk menerapkannya. Ada negara bagian yang menerapkan sistem kredit untuk setiap mata pelajaran. Setiap satu mata pelajaran rentang kreditnya antara 10-20 kredit per semester.

Landasan filosofis kurikulum sejarah tidak hanya dapat dilihat dari sisi penamaan mata pelajaran, tetapi juga dapat ditinjau dari tujuan yang mau dicapai mata pelajaran sejarah itu. Untuk itu perlu memperhatikan tujuan mata pelajaran sejarah baik di Indonesia maupun di Australia sebagaimana tabel berikut ini. 
Perbandingan Tujuan Mata Pelajaran Sejarah di Indonesia dan Australia

\begin{tabular}{|c|c|c|}
\hline \multicolumn{3}{|l|}{ NEGARA } \\
\hline \multicolumn{2}{|l|}{ INDONESIA } & \multirow[t]{2}{*}{ AUSTRALIA } \\
\hline Sejarah Indonesia (Umum) & Sejarah (Peminatan) & \\
\hline $\begin{array}{l}\text { Menumbuhkan kesadaran } \\
\text { dalam diri peserta didik sebagai } \\
\text { bagian dari bangsa Indonesia } \\
\text { yang memiliki rasa bangga dan } \\
\text { cinta tanah air, melahirkan } \\
\text { empatidan perilaku toleran yang } \\
\text { dapat diimplementasikan dalam } \\
\text { berbagai bidang kehidupan } \\
\text { masyarakat dan bangsa. }\end{array}$ & $\begin{array}{l}\text { Mengembangkan pengetahuan } \\
\text { dan pemahaman mengenai } \\
\text { kehidupan masyarakat dan } \\
\text { bangsa Indonesia serta dunia } \\
\text { melalui pengalaman sejarah } \\
\text { bangsa Indonesia dan bangsa } \\
\text { lain. }\end{array}$ & $\begin{array}{l}\text { Mengembangkan pengetahu- } \\
\text { an dan pemahaman siswa } \\
\text { tentang masa lampau } \\
\text { dalam rangka menghargai } \\
\text { diri sendiri dan orang lain, } \\
\text { memahami masa sekarang } \\
\text { dan berkontrubusi untuk } \\
\text { memperdebatkan rencana } \\
\text { bagi masa datang. }\end{array}$ \\
\hline $\begin{array}{l}\text { Menumbuhkan pemahaman } \\
\text { peserta didik terhadap diri } \\
\text { sendiri, masyarakat, dan proses } \\
\text { terbentuknya bangsa Indonesia } \\
\text { melalui sejarah yang panjang } \\
\text { dan masih berproses hingga } \\
\text { masa kini dan masa yang akan } \\
\text { datang. }\end{array}$ & $\begin{array}{l}\text { Mengembangkan rasa } \\
\text { kebangsaan, cinta tanah air, dan } \\
\text { penghargaan kritis terhadap } \\
\text { hasil dan prestasi bangsa } \\
\text { Indonesia dan ummat manusia } \\
\text { di masa lalu. }\end{array}$ & $\begin{array}{lr}\text { M e } \mathrm{n} \text { g e } \mathrm{m} \text { b a } \mathrm{n} \text { g k a } \mathrm{n} \\
\text { kemampuan berpikir kritis } \\
\text { tentang masa lampau, } \\
\text { dan belajar bagaimana } \\
\text { membandingkan } & \text { cerita } \\
\text { sejarah yang berbeda } \\
\text { sehingga konflik } & \text { dan } \\
\text { perbedaan } & \text { dihargai. } \\
\text { Dengan demikian } & \text { sejarah } \\
\text { berkontribusi } & \text { dalam } \\
\text { membangun warga } & \text { negara } \\
\text { yang demokratis. } & \\
\end{array}$ \\
\hline $\begin{array}{l}\text { Mengembangkan perilaku yang } \\
\text { didasarkan pada nilai dan moral } \\
\text { yang mencerminkan karakter } \\
\text { diri, masyarakat, dan bangsa. }\end{array}$ & $\begin{array}{l}\text { Membangun kesadaran tentang } \\
\text { konsep waktu dan ruang dalam } \\
\text { berfikir kesejarahan. }\end{array}$ & $\begin{array}{l}\text { Memperkenalkan siswa } \\
\text { memahami sejarah } \\
\text { dengan terlibat dalam } \\
\text { metode penelitian sejarah. } \\
\text { Siswa belajar sejarah dan } \\
\text { mempraktikkannya. }\end{array}$ \\
\hline $\begin{array}{l}\text { Membangun kesadaran peserta } \\
\text { didik tentang pentingnya konsep } \\
\text { waktu dan tempat/ruang dalam } \\
\text { rangka memahami perubahan } \\
\text { dan keberlanjutan dalam } \\
\text { kehidupan bermasyarakat dan } \\
\text { berbangsa di Indonesia. }\end{array}$ & $\begin{array}{l}\text { Mengembangkan kemampuan } \\
\text { berpikir sejarah (historical } \\
\text { thinking), keterampilan sejarah } \\
\text { (historical skills), dan wawasan } \\
\text { terhadap isu sejarah (historical } \\
\text { issues) serta menerapkan } \\
\text { kemampuan, keterampilan, } \\
\text { dan wawasan tersebut dalam } \\
\text { kehidupan masa kini. }\end{array}$ & $\begin{array}{lrr}\text { Siswa harus } & \text { mempunyai } \\
\text { keterampilan } & \text { yang } \\
\text { luas tentang } & \text { sejarah } \\
\text { dengan terampil dalam } & \text { mencari sumber sejarah } \\
\text { dan } & \text { mengevaluasinya, } \\
\text { memahami konteks dan } \\
\text { menangkap makna referensi } \\
\text { tersebut. }\end{array}$ \\
\hline
\end{tabular}




\begin{tabular}{|l|l|l|}
\hline \multicolumn{2}{|c|}{ NEGARA } & AUSTRALIA \\
\hline \multicolumn{2}{|c|}{ INDONESIA Sejarah (Peminatan) } & \\
\hline $\begin{array}{l}\text { Menumbuhkan apresiasi dan } \\
\text { penghargaan peserta didik } \\
\text { terhadap peningalan sejarah } \\
\text { sebagai bukti peradaban bangsa }\end{array}$ & $\begin{array}{l}\text { Mengembangkan perilaku yang } \\
\text { didasarkan pada nilai dan moral } \\
\text { yang mencerminkan karakter } \\
\text { diri, masyarakat dan bangsa. }\end{array}$ & \\
\hline $\begin{array}{l}\text { Mengemesia di masa lampau. } \\
\text { berpikir historis (historical } \\
\text { thinking) yang menjadi dasar } \\
\text { untuk kemampuan berpikir } \\
\text { logis, kreatif, inspiratif, dan } \\
\text { inovatif. }\end{array}$ & $\begin{array}{l}\text { kepada kehidupan masa kini } \\
\text { dan masa depan berdasarkan } \\
\text { pengalaman masa lampau. }\end{array}$ & \\
\hline $\begin{array}{l}\text { Menanamkan sikap berorientasi } \\
\text { kepada masa kini dan masa } \\
\text { depan. }\end{array}$ & $\begin{array}{l}\text { Memahami dan mampu } \\
\text { menangani isu-isu kontroversial } \\
\text { untuk mengkaji permasalahan } \\
\text { yang terjadi di lingkungan } \\
\text { masyarakatnya. }\end{array}$ & \\
\hline & $\begin{array}{l}\text { Mengembangkan pemahaman } \\
\text { internasional dalam menelaah } \\
\text { fenomena aktual dan global. }\end{array}$ & \\
\hline
\end{tabular}

Secara filosofis tujuan kurikulum sejarah baik Sejarah Indonesia maupun Sejarah didalamnya terkandung landasan perenialisme, esensialisme, humanisme dan rekonstruksi sosial (Hasan, 2012:45). Pada pelajaran Sejarah Indonesia perenialisme terdapat pada tujuan pertama dan kelima. Esensialisme nampak pada tujuan keempat dan keenam. Humanisme ditemui pada tujuan ketiga dan rekonstruksi sosial terdapat pada tujuan ketujuh. Untuk pelajaran sejarah perenialisme ditemui pada tujuan kedua. Esensialisme didapatkan pada tujuan ketiga dan keempat. Humanisme terdapat pada tujuan kelima dan rekonstruksi sosial didapatkan pada tujuan keempat dan keenam.Selain landasan filosofis pada kedua mata pelajaran itu juga terdapat landasan politis dan akademik.Landasan politis Sejarah Indonesia terdapat pada tujuan kedua. Sedangkan pada sejarah ditemui pada tujuan kesatu. Dalam pada itu landasan akademik Sejarah Indonesia terdapat pada tujuan keenam dan sejarah pada tujuan ketujuh dan kedelapan. 
Berbeda dengan Indonesia, kurikulum sejarah di Australia yang dari segi filosofis lebih didominasi sudut pandang esensialisme. Sebab dari empat tujuan yang terdapat dalam kurikulum sejarah itu ada tiga tujuan yang memperlihatkan sudut pandang esensialisme yaitu pada tujuan kedua sampai keempat. Meskipun begitu kurikulum sejarah di Australia juga memperlihatkan adanya dasar pemikiran yang berangkat dari rekonstruksi sosial, akademik dan humanisme sebagaimana yang terdapat dalam tujuan kesatu dan kedua. Agar tercapai semua tujuan yang terdapat dalam kurikulum tersebut maka dikembangkanlah dalam bentuk materi yang harus dipelajari peserta didik.

\section{Materi Sejarah}

Materi sejarah yang dipelajari peserta didik di Indonesia ternyata jauh lebih banyak dan luas dibandingkan dengan yang dipelajari peserta didik di Australia. Peserta didik di Indonesia mempelajari 10 topik materi yang dibahas dalam pelajaran Sejarah Indonesia. Mulai dari pra-aksara sampai dengan reformasi. Materi yang dipelajari lebih menekankan bagaimana perjalanan hidup bangsa Indonesia sejak pra-aksara sampai reformasi. Apa yang dipelajari peserta didik dalam Sejarah Indonesia itu menemukan perluasan dan pendalaman dalam mata pelajaran Sejarah yang ditempuh peserta didik di program peminatanIlmu Pengetahuan Sosial (IPS). Ada 13 topik materi yang dipelajari peserta didik program IPS mulai dari prinsip dasar ilmu sejarah sampai Indonesia dan dunia pada masa revolusi teknologi informasi dan komunikasi.
Kalau dalam Sejarah Indonesia lebih menyoroti kondisi kedalam, maka dalam pelajaran sejarah yang dilihat bagaimana Indonesia dalam konteks sejarah dunia. Jadi pelajaran sejarah di kelas peminatan mengajak peserta didik membahas perjalanan hidup bangsa Indonesia yang tidak bisa dilepaskan dari kehidupan bangsa-bangsa lain, termasuk kemajuan dalam ilmu pengetahuan dan teknologi informasi. Lain halnya dengan peserta didik di Australia. Mereka melalui mata pelajaran Sejarah Kuno (Ancient History) dan Sejarah Modern (Modern History) tidak mempelajari seluruh unit atau topik yang disediakan sebagaimana halnya di Indonesia. Peserta didik diberi kesempatan memilih dari topik yang disediakan untuk mereka pilih sebagai bahan pembelajaran.

Pada kedua mata pelajaran itu masing-masingnya terdapat 4 unit. Namun setiap unit tidak sama banyak topik yang dibahas. Sejarah Kuno topiknya lebih banyak dibandingkan Sejarah Modern. Sejarah Kuno topik pilihannya antara 7-16 topikpada setiap unit dengan fokus pada peristiwa penting, masyarakat, periodesasi, situs, sumber atau isu sejarah. Sedangkan Sejarah Modern topik pilihannya antara 5-8 topik pada setiap unitnya dengan fokus pada gerakan dan perkembangan negara bangsa (negara modern).Topik-topik pilihan itu dapat dipilih oleh peserta didik sebanyak 1-2 baik yang terkait dengan pengetahuan dan pemahaman sejarah, maupun yang menyangkut keterampilan sejarah. Bagaimana perbandingan materi yang dipelajari peserta didik di Indonesia dengan Australia dapat dilihat pada tabel berikut. 
Perbandingan Materi Sejarah Yang Dipelajari Siswa Indonesia dan Australia

\begin{tabular}{|c|c|c|c|}
\hline \multicolumn{2}{|c|}{ INDONESIA (SMA/MA) } & \multicolumn{2}{|c|}{ AUSTRALIA (SSS) } \\
\hline Sejarah Indonesia & Sejarah & Ancient History & Modern Hisrory \\
\hline Praaksara & $\begin{array}{l}\text { Prinsip Dasar IImu } \\
\text { Sejarah }\end{array}$ & $\begin{array}{l}\text { Investigating the } \\
\text { Ancient World }\end{array}$ & $\begin{array}{l}\text { Understanding the } \\
\text { Modern World }\end{array}$ \\
\hline Hindu-Buddha & $\begin{array}{l}\text { Peradaban awal } \\
\text { masyarakat dunia dan } \\
\text { Indonesia }\end{array}$ & Ancient Societies & $\begin{array}{l}\text { Movement for Change } \\
\text { in the 20th Century }\end{array}$ \\
\hline $\begin{array}{l}\text { Kerajaan-kerajaan } \\
\text { Islam }\end{array}$ & $\begin{array}{l}\text { Perkembangan } \\
\text { negara-negara } \\
\text { tradisional di } \\
\text { Indonesia }\end{array}$ & $\begin{array}{l}\text { People, Power, and } \\
\text { Authority }\end{array}$ & $\begin{array}{l}\text { Modern Nations in the } \\
\text { 20th Century }\end{array}$ \\
\hline $\begin{array}{l}\text { Penjajahan bangsa } \\
\text { Barat }\end{array}$ & $\begin{array}{l}\text { Indonesia pada masa } \\
\text { penjajahan }\end{array}$ & $\begin{array}{l}\text { Reconstructing the } \\
\text { Ancient World }\end{array}$ & $\begin{array}{l}\text { The Modern World since } \\
1945\end{array}$ \\
\hline Pergerakan Nasional & $\begin{array}{l}\text { Revolusi besar dunia } \\
\text { dan pengaruhnya }\end{array}$ & & \\
\hline $\begin{array}{l}\text { Proklamasi dan } \\
\text { Perjuangan } \\
\text { mempertahankan } \\
\text { kemerdekaan } \\
\end{array}$ & $\begin{array}{l}\text { Kebangkitan heroisme } \\
\text { dan kebangsaan } \\
\text { Indonesia }\end{array}$ & & \\
\hline Demokrasi Liberal & $\begin{array}{l}\text { Proklamasi dan } \\
\text { perkembangan negara } \\
\text { kebangsaan Indonesia }\end{array}$ & & \\
\hline $\begin{array}{l}\text { Demokrasi } \\
\text { Terpimpin }\end{array}$ & $\begin{array}{l}\text { Perjuangan } \\
\text { mempertahankan } \\
\text { kemerdekaan Indonesia }\end{array}$ & & \\
\hline Orde Baru & $\begin{array}{l}\text { Dunia pada masa } \\
\text { Perang Dingin dan } \\
\text { perubahan politik } \\
\text { global }\end{array}$ & & \\
\hline Reformasi & $\begin{array}{l}\text { Indonesia pada masa } \\
\text { Demokrasi Liberal } \\
\text { dan Demokrasi } \\
\text { Terpimpin }\end{array}$ & & \\
\hline & $\begin{array}{l}\text { Indonesia pada masa } \\
\text { Orde Baru }\end{array}$ & & \\
\hline & $\begin{array}{l}\text { Indonesia pada masa } \\
\text { Reformasi }\end{array}$ & & \\
\hline & $\begin{array}{l}\text { Indonesia dan Dunia } \\
\text { pada masa Revolusi } \\
\text { Teknologi Informasi } \\
\text { dan Komunikasi. }\end{array}$ & & \\
\hline
\end{tabular}




\section{Metode dan Penilaian}

Berbagai topik materi di atas dalam proses pembelajaran ternyata antara peserta didik Indonesia dengan peserta didik Australia berbeda pengalaman yang ditempuh. Sebab metode pembelajaran yang berlangsung di Indonesia meskipun dengan menggunakan pendekatan saintifik yang berarti peserta didik dituntut dalam proses pembelajaran terutama menggunakan metode discovery learning, project based learning, dan problem based learning, tetapi tidak melatih peserta didik untukmelakukaninterpretasisebagaimana yang terjadi di Australia. Peserta didik di Australia dalam belajar sejarah terjun langsung dalam mendapatkan informasi tentang sejarah dengan mencari sumber dan merekonstruksinya, sehingga mereka harus mampu melakukan interpretasi dan menyajikannya. Itu dapat dilakukan secara individual dan bisa juga secara kelompok. Apa yang dilakukan oleh peserta didik di Australia itu juga memperlihatkan adanya pendekatan saintifik dalam metode pembelajarannya. Kurikulum sejarah di Australia memang tidak mengungkapkan secara eksplisit metode apa saja yang bisa digunakan dalam pembelajaran.

Setiap proses pembelajaran selalu diikuti dengan penilaian. Sebab penilaian merupakan salah satu komponen kegiatan dalam pembelajaran dalam rangka mengukur tercapai atau tidaknya tujuan pembelajaran sehingga diketahui sudah sejauh mana pencapaian yang didapat oleh peserta didik. Sehubungan dengan penilaian itu di Indonesia dilaksanakan dalam dua bentuk penilaian yaitu penilaian autentik dan non autentik. Penilaian autentik terdiri dari penilaian berdasarkan pengamatan, tugas ke lapangan, portofolio, projek, produk, jurnal, kerja laboratorium, unjuk kerja dan penilaian diri. Sedangkan penilaian non autentik bentuknya berupa tes, ulangan, dan ujian.Semua bentuk penilaian itu untuk mengetahui pencapaian kompetensi sikap spiritual dan sikap sosial, kompetensi pengetahuan, dan kompetensi keterampilan dari masingmasing peserta didik.

Secara umum pencapaian hasil pembelajaran di Australia dilaksanakan dengan menggunakan penilaian berbasis sekolah, ujian eksternal, dan tes eksternal berskala. Ujian berbasis sekolah bentuknya antara lain portofolio, laporan investigasi. Ujian eksternal diperoleh melalui kombinasi pilihan ganda, jawaban singkat, dan tugas-tugas tambahan. Ujian eksternal biasanya berlangsung ketika peserta didik akan mendapatkan sertifikat pertama yang dilaksanakan pada akhir pendidikan level 12. Namun setiap negara bagian berbedabeda dalam menerapkan sistem penilaian tersebut. Ada negara bagian yang untuk unit 1 dan 2 menggunakan penilaian berbasis sekolah, sementara unit 3 dan 4 merupakan gabungan penilaian berbasis sekolah dan ujian eksternal dimana persentasenya $70 \%$ berbasis sekolah dan $30 \%$ ujian eksternal.

\section{KESIMPULAN}

Sistem pendidikan Indonesia dan Australia tidak jauh berbeda antara satu dengan yang lain jika dilihat dari sisi jenjang pendidikan. Perbedaan yang ada lebih kepada masa studi pada masingmasing jenjang pendidikan.Perbedaan masa studi itupun tidak di seluruh negara bagian maupun teritori yang ada di Australia. Pada jenjang sekolah dasar Indonesia berbeda dengan Negara Bagian South Australia, Northern Territory, Queensland, dan Western Australia. Peserta didik di Indonesia hanya belajar 
selama 6 tahun, sementara negara bagian tersebut berlangsung selama 7 tahun. Sebaliknya untuk jenjang pendidikan sekolah menengah tingkat pertama Indonesia dan Negara bagian tersebut lama pendidikan berlangsung 3 tahun. Perbedaan justru terjadi dengan Negara Bagian New South Wales, Victoria, Tasmania, dan Australia Capital Territory dimana proses pembelajaran berlangsung selama 4 tahun. Oleh karena perbedaan yang terjadi di tingkat sekolah menengah pertama maka akhirnya perbedaan itu berlangsung juga untuk jenjang pendidikan sekolah menengah tingkat atas yang kalau di Indonesia berlangsung selama 3 tahun maka di Australia hanya berlangsung 2 tahun.

Pada jenjang pendidikan tinggi untuk memperoleh gelar sarjana di Indonesia bisa diperoleh dalam jangka waktu 4 tahun. Sebaliknya di Australia diperoleh dalam jangka waktu 3 tahun. Untuk program gelar magister (Indonesia) atau master (Australia), peserta didik di Australia bisa menyelesaikan pendidikan lebih cepat daripada peserta didik di Indonesia. Sedangkan untuk program doktor ternyata lama masa studinya tidak ada perbedaan antara Indonesia dan Australia.

Kurikulum pendidikan sejarah antara Indonesia dan Australia secara filosofis terdapat perbedaan. Secara filosofis pendidikan sejarah di Indonesia lebih banyak aspeknya, tidak seperti Australia yang didominasi filosofis esensialisme. Oleh karenaitu maka dari sisi pembelajaran meskipun sama-sama pendekatan saintifik, tetapi peserta didik di Australia didorong untuk mampu mengembangkan kemampuan interpretasi ketika mereka ditugaskan membuat karya tulis baik secara kelompok maupun individu.Dalam hal metode pembelajaran kurikulum di Indonesia secara eksplisit menyebutkan berbagai metode yang utama dapat dilaksanakan. Sebaliknya di Australia tidak secara eksplisit mengungkapkan metode pembelajaran yang diterapkan. Selain itu peserta didik di Australia dalam belajar sejarah materinya tidak sebanyak peserta didik di Indonesia. Jika di Indonesia peserta didik mempelajari semua topik yang terdapat dalam kurikulum, maka di Australia peserta didik hanya memilih topik-topik tertentu yang memang mereka minati untuk didalami.

\section{Daftar Pustaka}

Acara. The Shape of The Australian Curriculum Version 4.0, 2012. . Curriculum Design Paper Version 3.1, Sydney, Acara, 2013.

.The Australian Curriculum Version 7.2, 2014.

Arta,Ketut Sedana. "Kurikulum dan Kontroversi Buku Teks Sejarah Dalam KTSP," Media Komunikasi FIS, Vol II No. 1, April 2012.

Australian Education Act 2013.

Australian Education Bill2012.

Australian Education International. Country Education Profiles Australia, Department of Industry, Innovation, Science, Research and Tertiary Education, Australian Government.

Biro Pusat Statistik.Hasil Sensus Penduduk SP 2000, Jakarta, Bagian Publikasi Sekretariat Badan Nasional Pusat Statistik, 2011.

Department Immigration and Border Protection. The People Of Australia Statistics From The 2011 Census, Commonwealth of Australia, 2014.

Hafid, Anwar Jafar Ahiri, dan Pendais 
Haq. Konsep Dasar Ilmu Pendidikan, Bandung, Alfabeta, 2014.

Hasan, Hamid. Pendidikan Sejarah Indonesia Isu dalam Ide dan Pembelajaran, Bandung, Rizqi Press, 2012.

Lampiran I Peraturan Menteri Pendidikan dan Kebudayaan Republik Indonesia No. 59 Tahun 2014 tentang Kurikulum 2013 Sekolah Menengah Atas/Madrasah Aliyah

Melbourne Declaration on Educational Goals for Young Australians December 2008

Mudyahardjo, Redja. Pengantar Pendidikan Sebuah Studi Awal tentang DasarDasar Pendidikan Pada Umumnya dan Pendidikan di Indonesia, Jakarta, Rajawali Pers, 2014.

Nur, Agustiar Syah. Perbandingan Sistem Pendidikan 15 Negara, Bandung, Lubuk Agung, 2001.

Peraturan Pemerintah Republik Indonesia No. 19 Tahun 2005 tentang Standar Nasional Pendidikan.

Peraturan Menteri Pendidikan dan Kebudayaan Republik Indonesia No. 104 Tahun 2014 tentang Penilaian Hasil Belajar Oleh Pendidik Pada Pendidikan Dasar dan Pendidikan Menengah.

Sunarti dan Selly Rahmawati. Penilaian Kurikulum 2013 Membantu Guru dan Calon Guru Mengetahui LangkahLangkah Penilaian Pembelajaran, Yogyakarta, Penerbit Andi, 2014.

Tirtarahardja, Umar dan La Sulo. Pengantar Pendidikan, Jakarta, Rineka Cipta, 2012.

Undang-Undang Republik Indonesia Nomor 20 Tahun 2003 tentang Sistem Pendidikan Nasional.

Walker, Decker. Fundamentals of Curriculum, Orlando, Harcourt Brace Jovanovich Inc., 1990.
Widoyoko, S. Eko Putro. Penilaian Hasil Pembelajaran di Sekolah, Yogyakarta, Pustaka Pelajar, 2014.

www.indonesia.embassy.gov. aufilesjaktLF_sistem_pemerintahan. pdf diakses tanggal 10 Maret 2015 pukul 10.25 . 